\title{
Pembuatan Model Pemeringkatan Ulasan Menggunakan Metode Random Forest Regression
}

\author{
Nisrina Fadhilah Fano**1, Arif Djunaidy ${ }^{2}$ \\ ${ }^{1,2}$ Departemen Sistem Informasi, Fakultas Teknologi Elektro Dan Informatika Cerdas \\ Institut Teknologi Sepuluh Nopember Surabaya \\ e-mail: *11nisrinafano.19052@mhs.its.ac.id, ${ }^{2}$ adjunaidy@its.ac.id
}

\begin{abstract}
Abstrak
Di tengah perkembangan teknologi yang cepat, internet telah mengubah gaya hidup masyarakat, seperti dalam hal berbelanja barang. Dalam melakukan pembelanjaan melalui internet, salah satu hal yang perlu diperhatikan adalah ulasan pelanggan. Permasalahan muncul ketika jumlah ulasan pelanggan yang ada sangat besar, sehingga jumlah informasi yang tersedia terlalu banyak. Untuk menyelesaikan permasalahan ini, beberapa platform belanja dalam jaringan (daring) mengurutkan ulasan pelanggan dari yang paling membantu hingga kurang membantu. Namun sistem ini memiliki beberapa kekurangan, salah satunya adalah dapat dimanipulasi. Maka dibutuhkan suatu cara lain untuk menentukan apakah sebuah ulasan dapat membantu calon pelanggan memutuskan pembelian produk. Penelitian ini bertujuan untuk membuat sebuah model pemeringkatan ulasan berdasarkan tingkat kegunaan ulasan hasil regresi. Metode yang digunakan pada penelitian ini adalah Random Forest Regression. Terdapat enam tahapan utama pada metodologi ini, dimulai dari pengumpulan data ulasan pelanggan, praproses data, ekstraksi aspek dan analisis sentiment aspek untuk menentukan polaritas aspek, pembuatan model regresi dan pemeringkatan, dan analisis hasil. Hasil penelitian menunjukkan bahwa model pemeringkatan yang dibuat berdasarkan hasil regresi mempunyai kinerja yang lebih unggul dibandingkan dengan model yang dibuat hanya berdasarkan nilai helpfulness ratio saja. Hal ini dibuktikan dengan model tersebut unggul pada pengujian nilai kecocokan yang dilakukan dengan peningkatan kinerja sebesar $6 \%$.
\end{abstract}

Kata kunci - Tingkat Kegunaan Ulasan, Ulasan pelanggan, Aspek Produk, Regresi Random Forest

\begin{abstract}
In the midst of rapid technological developments, the internet has changed people's lifestyles, such as in terms of shopping. When shopping via the internet, one thing that needs to be considered is customer reviews. The problem arises when the number of existing customer reviews is very large, so the amount of information available is too much. To solve this problem, some online shopping platforms rank customer reviews from most helpful to least helpful. However, this system has several drawbacks, one of which is that it can be manipulated. So another way is needed to determine whether a review can help a potential customer decide to purchase a product. This study aims to create a review ranking model based on the review helpfulness from the regression review results. The method used in this study is the Random Forest Regression. There are six primary stages in this methodology, starting from collecting customer review data, preprocessing data, extracting aspects and analyzing aspect sentiment to determine the polarity of aspects, creating regression models and ranking, and analyzing the results. The results showed that the ranking model made based on the regression results had a superior performance compared to the model made based on the value of the helpfulness ratio alone. This is evidenced by the model being superior in testing the matching score which was carried out with an increase in performance of $6 \%$.
\end{abstract}


Keywords - Review Helpfulness, Customer Reviews, Product Aspect, Random Forest Regression

\section{PENDAHULUAN}

$\mathrm{U}$ lasan pelanggan merupakan salah satu fitur yang disediakan oleh pada penyedia layanan belanja dalam jaringan (daring) bagi para pelanggan agar dapat memberikan ulasan produk atau layanan pada website penyedia layanan belanja setelah membeli sebuah produk atau menggunakan sebuah layanan. Ulasan pelanggan dapat memberikan informasi mengenai pengalaman pelanggan dalam menggunakan produk atau layanan, serta dapat memberikan informasi lebih detail dari produk atau layanan tersebut [1]. Sebanyak 70\% calon pelanggan mempercayai hal-hal yang terdapat pada ulasan pelanggan lain [2]. Hal ini menjadikan ulasan pelanggan sebagai sumber informasi terpercaya kedua setelah rekomendasi keluarga dan kerabat, serta mempunyai pengaruh yang kuat pada keputusan pelanggan dalam membeli barang [3]. Ulasan pelanggan juga mempunyai potensi untuk meningkatkan kemampuan pelanggan untuk membuat keputusan belanja yang lebih bijak [4]. Permasalahan muncul ketika jumlah ulasan pelanggan yang ada sangat besar, sehingga jumlah informasi yang tersedia terlalu banyak [1]. Maka dibutuhkan suatu cara untuk menentukan apakah sebuah ulasan dapat membantu calon pelanggan memutuskan untuk membeli produk atau tidak. Zhou mengatakan bahwa sebuah ulasan yang membantu adalah ulasan yang memfasilitasi proses keputusan belanja oleh calon pelanggan. Selain itu, ulasan juga harus dapat mendeskripsikan kualitas dari produk atau jasa [1] sehingga dapat mengurangi tingkat ketidakpastian dalam berbelanja [5].

Pada umumnya, ulasan pelanggan terdiri dari dua bagian, yaitu rating produk atau layanan dengan skala tertentu dan ulasan produk atau layanan [6]. Dari ulasan pelanggan, pembaca ulasan dapat mengetahui pengalaman pelanggan terhadap penggunaan sebuah produk atau layanan secara detail. Terdapat beberapa fitur yang dapat dieksplorasi pada ulasan pelanggan, seperti helpfulness, informativeness, readability, dan fitur lainnya.

Tingkat kegunaan ulasan atau yang biasa disebut dengan review helpfulness merupakan salah satu fitur paling penting yang terdapat pada ulasan pelanggan [1]. Menurut Mudambi dan Schuff, tingkat kegunaan ulasan didefinisikan sebagai tingkatan dimana pelanggan lain percaya bahwa ulasan dapat membantu untuk membuat keputusan dalam berbelanja [6]. Tingkat kegunaan sebuah ulasan dapat dipengaruhi oleh beberapa faktor. Berdasarkan studi yang dilakukan oleh Sun, faktor-faktor tersebut dapat dikelompokkan ke dalam dua bagian, yaitu faktor isi ulasan dan faktor penulis ulasan [5]. Dari aspek ulasan, ada beberapa faktor yang ditemukan oleh peneliti sebelumnya, yaitu panjang ulasan, bahasa yang digunakan [7], sudut pandang yang digunakan [8], hingga polaritas sentiment ulasan [9]. Dari seluruh faktor tersebut, yang paling berpengaruh adalah panjang ulasan yang didapatkan dari jumlah kata dalam ulasan tersebut [10] [11]. Hal ini menunjukkan bahwa semakin banyak informasi yang diberikan dalam sebuah ulasan, akan semakin membantu calon pelanggan. Akan tetapi dalam sebuah ulasan yang panjang tidak selalu berisi tentang informasi yang berguna. Maka dari itu, Sun menggunakan jumlah atribut yang ada pada ulasan [5]. Semakin banyak jumlah atribut produk yang disebutkan, maka ulasan tersebut lebih membantu calon pelanggan. Studi lain melakukan analisis sentimen pada sebuah ulasan. Namun terdapat beberapa pertentangan pada hasilnya, dimana Eslami dan Li menyatakan bahwa ulasan yang mengandung polaritas sentiment negatif lebih berguna [4] [7], namun Salehan dan Kim menyatakan bahwa ulasan yang mengandung polaritas sentimen netral dengan terdapat sentimen positif dan negatif di dalamnya akan lebih berguna bagi calon pelanggan [10]. Salah satu isu pada faktor polaritas sentiment ulasan adalah

Fano, et., al [Pembuatan Model Pemeringkatan Ulasan Menggunakan Metode Random Forest Regression] 
konsistensi. Zhou menemukan bahwa polaritas sentiment judul ulasan yang sesuai dengan polaritas sentiment ulasan akan lebih membantu bagi calon pelanggan [1].

Salah satu manfaat dalam mengetahui tingkat kegunaan ulasan adalah dengan menggunakan tingkat kegunaan ulasan tersebut untuk mengurutkan ulasan-ulasan yang ada pada website belanja daring. Beberapa penelitian telah dilakukan untuk mencari cara yang efektif untuk mengurutkan ulasan atau melakukan pemeringkatan pada ulasan. Pada model pemeringkatan yang tidak memperhatikan isi ulasan, terdapat tiga cara yang umum digunakan oleh para penyedia layanan belanja daring, yaitu MRF (Most Recent First) yang didasarkan pada waktu ditulisnya ulasan, MHF (Most Helpful First) yang didasarkan pada jumlah helpful vote yang diberikan oleh pengguna, dan HRF (Helpfulness Ratio First) yang didasarkan pada nilai perbandingan antara jumlah helpful vote yang diterima dengan jumlah keseluruhan vote [12]. Dari ketiga metode yang telah disebutkan, seluruhnya menggunakan waktu dan jumlah helpful vote yang diterima oleh ulasan. Hal ini akan menjadi masalah apabila suatu ulasan yang tidak memiliki helpful vote namun sesungguhnya ulasan tersebut memiliki tingkat kegunaan yang baik, maka ulasan tersebut tidak dapat ditampilkan dalam posisi awal. Permasalahan lain muncul apabila proses pemeringkatan hanya menggunakan nilai helpfulness ratio. Jumlah helpful vote dan unhelpful vote dapat dimanipulasi, sehingga model pemeringkatan tidak lagi dapat dipercaya.

Maka pada penelitian ini dilakukan pembuatan model pemeringkatan ulasan pelanggan yang tidak hanya berdasarkan nilai helpfulness ratio ataupun waktu penulisan ulasan saja, namun model pemeringkatan yang diajukan menggunakan hasil regresi sebagai dasar penentuan peringkat ulasan.

\section{METODE PENELITIAN}

Metode Metodologi pada penelitian ini mengadaptasi metodologi yang digunakan oleh Sunil Saumya untuk melakukan pemeringkatan ulasan [13]. Metodologi yang digunakan terdiri dari enam tahap seperti yang terdapat pada Gambar 1, meliputi: (1) Pengumpulan Data, (2) Praproses Data, (3) Ekstraksi Aspek dan Analisis Sentimen, (4) Pembuatan Model Regresi, (5) Melakukan Pemeringkatan Ulasan, dan (6) Analisis Hasil Pemeringkatan.
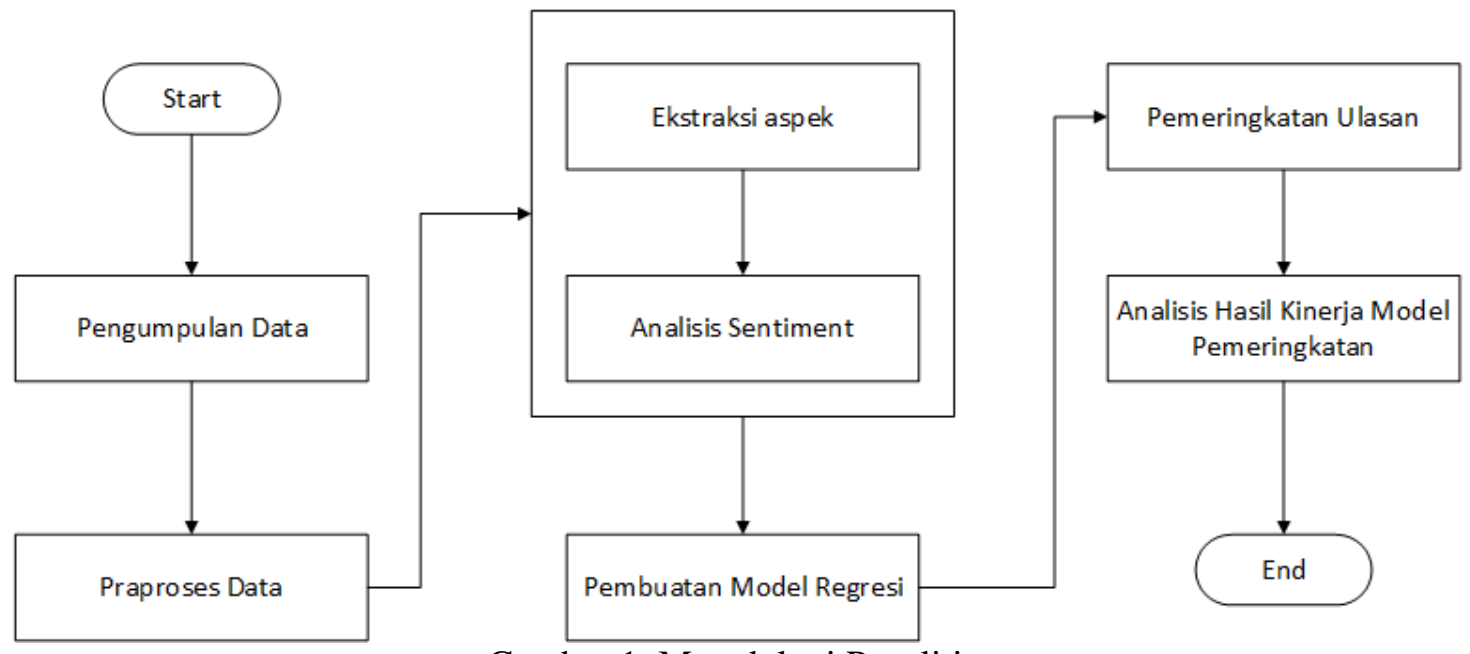

Gambar 1. Metodologi Penelitian 


\subsection{Pengumpulan Data}

Proses pengumpulan data dilakukan dengan metode web scraping. Data yang digunakan pada penelitian ini merupakan data ulasan produk pada tahun 2014 - 2020 yang didapatkan dari tiga website, yaitu Flipkart, Bol, dan Ceneo. Data yang diambil merupakan data ulasan dari produk pendingin ruangan, mesin cuci, kulkas, televisi, dan kamera. Total data yang terkumpul dari situs Flipkart adalah 69.415 data ulasan, dari situs Bol sebanyak 5.229 data ulasan, dan dari situs Ceneo sebanyak 7.620 data ulasan. Sehingga total data yang terkumpul adalah 82.334. Masing-masing baris data ulasan yang dikumpulkan mempunyai 11 atribut. Atribut data yang diambil meliputi nama produk, harga produk, rating produk, nama penjual, rating penjual, teks ulasan, judul ulasan, nama pemberi ulasan, rating produk yang diberikan oleh ulasan, jumlah helpful vote dan jumlah unhelpful vote.

\subsection{Praproses Data}

Pada tahap praproses data, terdapat lima aktivitas yang dilakukan. Tahap praproses data yang digunakan pada penelitian ini mengadaptasi langkah-langkah yang dilakukan pada penelitian Mowlaei [14]. Tahap praproses data meliputi :

- Menghapus simbol yang tidak digunakan

Simbol yang muncul pada data ulasan seperti simbol mata uang akan dihapus agar tidak mengganggu proses ekstraksi aspek.

- Menghapus ulasan yang terdeteksi sebagai spam

Ulasan yang terindikasi sebagai ulasan spam diidentifikasi melalui beberapa kriteria, meliputi mempunyai nilai rating yang jauh berbeda dengan rating rata-rata produk dan hanya terdiri dari satu kata.

- Melakukan tokenisasi kata pada teks ulasan

Teks ulasan yang terdiri dari satu atau lebih kalimat akan dipisah menjadi kata-kata. Proses tokenisasi dilakukan dengan menggunakan library fungsi RegexpTokenizer() dari library nltk pada Python.

- Menghilangkan stopwords

Stopwords merupakan kata-kata yang sering muncul namun kurang memiliki makna apabila berdiri sendiri. Dalam tahap ini, kata-kata yang termasuk dalam kumpulan kata stopwords akan dihapus. Kumpulan kata stopwords yang digunakan diperoleh dari library nltk pada Python.

- Melakukan lematisasi

Pada tahap ini dilakukan pengubahan kata-kata dalam ulasan menjadi kata dasar. Proses lemmatisasi dilakukan dengan menggunakan WordNetLemmatizer() yang didapat dari library nltk. Kata-kata yang diubah ke dalam bentuk dasar meliputi kata benda dan kata kerja

\subsection{Ekstraksi Aspek dan Analisis Sentimen}

Tahap ekstraksi aspek dibagi ke dalam dua bagian, meliputi ekstraksi aspek eksplisit dan ekstraksi aspek implisit. proses dilakukan dengan cara membandingkan kata-kata dalam ulasan dengan sekelompok kata-kata aspek yang telah ditentukan sebelumnya. Sekelompok kata aspek tersebut didapatkan dari dua sumber, yaitu fitur dan spesifikasi yang terdapat pada deskripsi produk serta kata-kata yang paling sering disebutkan pada ulasan. Selain membandingkan kata yang akan menjadi kandidat aspek dengan kata-kata aspek, kata kandidat kemudian akan dibandingkan dengan sinonim dari kata-kata aspek. Penentuan sinonim katakata aspek dilakukan dengan menggunakan corpus WordNet dari library nltk.

Pada ekstraksi aspek implisit, kata-kata hasil praproses dimasukkan dalam proses POStagging menggunakan library spacy pada Python. Tahap ekstraksi aspek implisit kemudian 
dilakukan dengan cara mencocokkan tag yang didapat dari hasil POS-tagging dengan aturan yang ada untuk mendapatkan aspek [15]. Aturan yang digunakan meliputi:

- Apabila sebuah kata sifat (ADJ) diikuti kata benda (NOUN), maka kata benda tersebut akan ditandai sebagai kandidat aspek.

- Apabila sebuah kata benda (NOUN) diikuti oleh kata sifat (ADJ), maka kata benda tersebut akan ditandai sebagai kandidat aspek.

- Apabila sebuah kata kerja (VERB) diikuti oleh kata benda (NOUN), maka kata benda tersebut akan ditandai sebagai kandidat aspek.

Setelah kata-kata tersebut ditandai sebagai kandidat aspek, kata-kata tersebut akan dicek, apakah kata tersebut sudah ditandai sebagai aspek pada tahap ekstraksi eksplisit. Jika sudah, maka kata tersebut tidak diproses sebagai aspek implisit agar tidak terjadi adanya aspek yang muncul dua kali. Apabila kata tersebut tidak ditandai sebagai aspek pada ekstraksi eksplisit, maka langkah selanjutnya akan dilakukan penghitungan nilai PMI-IR (Pointwise Mutual Information - Information Retrieval) terhadap kata tersebut [15]. Persamaan (1) digunakan untuk menghitung nilai SO dari kandidat aspek.

$$
S O(\text { frasa })=\log _{2}\left(\frac{\text { hits }(\text { frasa NEAR } p) \times \text { hits }(s)}{\text { hits }(\text { frasa NEAR }) \times \operatorname{hits}(p)}\right)
$$

Nilai SO(frasa) kemudian digunakan untuk menentukan apakah kandidat aspek akan ditandai sebagai aspek produk, aspek layanan, atau bukan aspek. Apabila nilai $\mathrm{SO}$ (frasa) di atas 0.5 , maka kandidat aspek akan ditandai sebagai aspek produk. Apabila nilai $\mathrm{SO}$ (frasa) lebih kecil dari -1.2, maka kandidat aspek akan ditandai sebagai aspek layanan. Sedangkan apabila nilai $\mathrm{SO}$ (frasa) terdapat dalam rentang $-1.2<\mathrm{SO}$ (frasa) $<0.5$, maka kata tersebut tidak akan ditandai sebagai aspek.

Setelah aspek berhasil diidentifikasi, tahap selanjutnya adalah penentuan sentiment aspek pada suatu ulasan. Menurut Brunova dan Bidulya, dalam suatu teks, kata-kata yang mengandung aspek dan opini biasanya berada dalam jarak yang dekat, yaitu radius 3 kata [16]. Maka dari itu, kata yang berada pada radius tersebut dari kata aspek akan diidentifikasi sebagai kandidat opini. Kata-kata yang diidentifikasi sebagai kandidat opini kemudian akan dibandingkan dengan list opini positif dan list opini yang didapat dari opinion lexicon yang disusun oleh Bing \& Liu [17]. Setelah itu juga dilakukan pengecekan keberadaan kata negasi. Apabila ditemukan adanya kata negasi sebelum kandidat opini, maka sentimen aspek akan berubah. Kandidat opini yang ditandai positif akan diberi nilai +1 . Sedangkan kandidat opini yang ditandai negatif akan diberi nilai -1 . Kandidat opini tersebut kemudian akan dinyatakan sebagai opini untuk aspek yang terdekat. Hasil akhir sentiment ulasan akan dibagi menjadi dua, yaitu sentimen untuk produk dan sentimen untuk layanan. Sentimen untuk produk didapatkan dari jumlah nilai seluruh opini untuk aspek produk dan sentimen layanan juga didapatkan dari jumlah nilai seluruh opini untuk aspek layanan.

\subsection{Pembuatan Model Regresi}

Model regresi yang digunakan pada penelitian ini adalah Random Forest Regression. Terdapat delapan variabel yang akan digunakan dalam model regresi, meliputi harga barang, rating produk, rating penjual, usia ulasan, rating pada ulasan. Nilai seluruh variabel tersebut didapatkan dari hasil pengumpulan data. Sedangkan untuk variabel jumlah aspek produk dan nilai sentimen aspek produk diperoleh dari hasil ekstraksi aspek dan analisis sentimen pada teks ulasan. Variabel terakhir yang digunakan adalah helpfulness ratio yang didapatkan dengan persamaan (2).

$$
\text { Helpfulness }=\frac{\text { Helpful vote }}{\text { Helpful vote }+ \text { Unhelpful vote }}
$$


Jumlah pohon yang digunakan pada Random Forest sebanyak 800 trees. Metode validasi yang digunakan untuk memvalidasi hasil regresi adalah $k$-fold cross-validation.

\subsection{Pembuatan Model Pemeringkatan}

Pemeringkatan ulasan dilakukan dengan mengadaptasi metode yang dilakukan oleh Sunil Saumya dengan mengurutkan data ulasan berdasarkan nilai hasil regresi [13]. Ulasan yang mempunyai nilai regresi tertinggi akan menduduki peringkat pertama.

\subsection{Analisis Hasil Pemeringkatan}

Hasil pemeringkatan yang telah dilakukan pada tahap ke lima kemudian akan dievaluasi dengan membandingkan model pemeringkatan hasil regresi dengan pemeringkatan yang dilakukan oleh pakar. Hasil dari evaluasi adalah nilai kecocokan, yang kemudian akan dibandingkan antara model pemeringkatan berdasarkan hasil regresi dan model pemeringkatan hanya berdasarkan nilai helpfulness ratio.

\section{HASIL DAN PEMBAHASAN}

Untuk mengetahui pengaruh penggunaan model regresi sebagai dasar pada model pemeringkatan ulasan, maka dalam penelitian ini dilakukan pengujian perbandingan nilai kecocokan. Uji perbandingan nilai kecocokan dilakukan dengan cara membandingkan nilai kecocokan dari kedua model. Model yang lebih baik adalah model yang mempunyai nilai kecocokan lebih baik. Sebelum menghitung nilai kecocokan, kami melakukan proses validasi pemeringkatan kepada 5 orang pakar. Pemilihan pakar dilakukan berdasarkan dua kriteria, yaitu:

- Pernah berbelanja barang secara online minimal satu kali dalam satu bulan

- Pernah berbelanja barang elektronik via online

Kelima orang tersebut kemudian kami minta untuk memberi peringkat pada data validasi. Data validasi merupakan data ulasan yang dipilih secara acak sebanyak 30. Dari 30 data tersebut, diambil 10 data ulasan teratas hasil pemeringkatan yang dilakukan oleh masingmasing pakar untuk dibandingkan oleh 10 data validasi teratas hasil pemeringkatan berdasarkan hasil regresi [13]. Nilai kecocokan didapat dengan menghitung berapa banyak ulasan yang terdapat pada kedua kumpulan data ulasan tersebut. Persamaan untuk menghitung nilai kecocokan terdapat pada (3).

\section{Nilai Kecocokan $=10$ Ulasan Teratas Regresi $\cap 10$ Ulasan Teratas Helpfulness}

Hasil penghitungan nilai kecocokan pada model dengan aspek layanan untuk data ulasan dari website Flipkart ditampilkan pada Tabel 1. Dalam Tabel 1 dapat terlihat bahwa ratarata persentase kecocokan hasil pemeringkatan berdasarkan model regresi dengan hasil pemeringkatan oleh pakar pada data ulasan produk pendingin ruangan dari website Flipkart adalah $42 \%$. Pada data ulasan produk mesin cuci, rata-rata nilai kecocokannya adalah $44 \%$. Sedangkan untuk rata-rata nilai kecocokan terkecil terdapat pada data ulasan produk kulkas dengan rata-rata persentase $20 \%$. 
Tabel 1. Hasil Penghitungan Nilai Kecocokan pada Data Ulasan dari Situs Web Flipkart

\begin{tabular}{|l|c|c|c|c|c|c|}
\hline \multirow{2}{*}{ Jenis Produk } & \multicolumn{5}{|c|}{ Pakar } & $\begin{array}{c}\text { Rata- } \\
\text { rata }\end{array}$ \\
\cline { 2 - 6 } & $\mathbf{1}$ & $\mathbf{2}$ & $\mathbf{3}$ & $\mathbf{4}$ & $\mathbf{5}$ & $42 \%$ \\
\hline $\begin{array}{l}\text { Pendingin } \\
\text { Ruangan }\end{array}$ & $40 \%$ & $40 \%$ & $50 \%$ & $50 \%$ & $30 \%$ & \multirow{2}{*}{$\begin{array}{l}42 \% \\
\text { Mesin Cuci }\end{array}$} \\
\hline Televisi & $30 \%$ & $60 \%$ & $60 \%$ & $30 \%$ & $40 \%$ & $44 \%$ \\
\hline Kulkas & $10 \%$ & $10 \%$ & $30 \%$ & $40 \%$ & $20 \%$ & $22 \%$ \\
\hline Kamera & $30 \%$ & $20 \%$ & $20 \%$ & $20 \%$ & $10 \%$ & $20 \%$ \\
\hline
\end{tabular}

Hasil penghitungan nilai kecocokan antara peringkat hasil model regresi dengan peringkat yang diberikan oleh manusia pada data ulasan dari situs web Bol dapat dilihat pada Tabel 2. Dalam Tabel 2 dapat terlihat bahwa rata-rata nilai kecocokan pada ulasan produk pendingin ruangan adalah $44 \%$, terbesar dibandingkan nilai pada produk lainnya. Sedangkan pada produk mesin cuci, rata-rata nilai kecocokannya adalah sebesar $24 \%$. Pada produk kulkas dan kamera, rata-rata nilai kecocokan dari hasil pemeringkatan adalah $40 \%$. Pada ulasan produk televisi, rata-rata nilai kecocokan yang didapat adalah $32 \%$.

Tabel 2. Hasil Penghitungan Nilai Kecocokan pada Data Ulasan dari Situs Web Bol

\begin{tabular}{|l|c|c|c|c|c|c|}
\hline \multirow{2}{*}{ Jenis Produk } & \multicolumn{5}{|c|}{ Pakar } & $\begin{array}{c}\text { Rata- } \\
\text { rata }\end{array}$ \\
\cline { 2 - 6 } & $\mathbf{1}$ & $\mathbf{2}$ & $\mathbf{3}$ & $\mathbf{4}$ & $\mathbf{5}$ & $44 \%$ \\
\hline $\begin{array}{l}\text { Pendingin } \\
\text { Ruangan }\end{array}$ & $40 \%$ & $50 \%$ & $50 \%$ & $40 \%$ & $40 \%$ & \multirow{2}{*}{ ( } \\
\hline Mesin Cuci & $20 \%$ & $30 \%$ & $30 \%$ & $20 \%$ & $20 \%$ & $24 \%$ \\
\hline Televisi & $20 \%$ & $30 \%$ & $40 \%$ & $40 \%$ & $30 \%$ & $32 \%$ \\
\hline Kulkas & $30 \%$ & $40 \%$ & $40 \%$ & $50 \%$ & $40 \%$ & $40 \%$ \\
\hline Kamera & $40 \%$ & $50 \%$ & $50 \%$ & $40 \%$ & $20 \%$ & $40 \%$ \\
\hline
\end{tabular}

Hasil penghitungan nilai kecocokan hasil pemeringkatan berdasarkan nilai regresi dengan peringkat yang diberikan oleh manusia pada data ulasan dari situs web Ceneo dapat dilihat pada Tabel 3. Dalam Tabel 3 dapat terlihat bahwa rata-rata nilai kecocokan hasil pemeringkatan pada data ulasan produk pendingin ruangan adalah $50 \%$. Sedangkan rata-rata nilai kecocokan pada ulasan produk mesin cuci adalah $42 \%$. Pada ulasan produk kulkas, rata-rata nilai kecocokan yang didapat adalah $46 \%$. Rata-rata nilai kecocokan yang didapat dari ulasan produk televisi adalah sebesar $36 \%$. Sedangkan rata-rata nilai kecocokan yang didapat pada ulasan produk kamera adalah $42 \%$.

Tabel 3. Hasil Penghitungan Nilai Kecocokan pada Data Ulasan dari Situs Web Ceneo

\begin{tabular}{|l|c|c|c|c|c|c|}
\hline \multirow{2}{*}{ Jenis Produk } & \multicolumn{5}{|c|}{ Pakar } & $\begin{array}{c}\text { Rata- } \\
\text { rata }\end{array}$ \\
\cline { 2 - 6 } & $\mathbf{1}$ & $\mathbf{2}$ & $\mathbf{3}$ & $\mathbf{4}$ & $\mathbf{5}$ & $50 \%$ \\
\hline $\begin{array}{l}\text { Pendingin } \\
\text { Ruangan }\end{array}$ & $40 \%$ & $40 \%$ & $50 \%$ & $60 \%$ & $60 \%$ & $50 \%$ \\
\hline Mesin Cuci & $30 \%$ & $50 \%$ & $20 \%$ & $50 \%$ & $60 \%$ & $42 \%$ \\
\hline Televisi & $20 \%$ & $40 \%$ & $40 \%$ & $40 \%$ & $40 \%$ & $36 \%$ \\
\hline Kulkas & $50 \%$ & $50 \%$ & $30 \%$ & $40 \%$ & $60 \%$ & $46 \%$ \\
\hline Kamera & $60 \%$ & $50 \%$ & $40 \%$ & $60 \%$ & $40 \%$ & $42 \%$ \\
\hline
\end{tabular}

Dari penghitungan nilai kecocokan antara peringkat hasil model regresi dengan peringkat yang diberikan manusia dapat disimpulkan bahwa rata-rata nilai kecocokan yang didapat 
sebesar 37\%\% seperti yang terlihat pada Tabel 4. Dalam Tabel 4 dapat terlihat bahwa rata-rata nilai kecocokan hasil pemeringkatan pada situs web Flipkart sebesar $30 \%$. Rata-rata nilai kecocokan hasil pemeringkatan pada data ulasan dari situs web Bol adalah sebesar 36\%. Nilai kecocokan hasil pemeringkatan pada data ulasan dari situs web Ceneo mempunyai rata-rata sebesar $43 \%$.

Tabel 4. Rata-rata Nilai Kecocokan Hasil Pemeringkatan

\begin{tabular}{|l|c|c|c|}
\hline \multicolumn{1}{|c|}{ Jenis Produk } & Flipkart & Bol & Ceneo \\
\hline Pendingin Ruangan & $42 \%$ & $44 \%$ & $50 \%$ \\
\hline Mesin Cuci & $44 \%$ & $24 \%$ & $42 \%$ \\
\hline Televisi & $22 \%$ & $32 \%$ & $36 \%$ \\
\hline Kulkas & $20 \%$ & $40 \%$ & $46 \%$ \\
\hline Kamera & $24 \%$ & $40 \%$ & $42 \%$ \\
\hline \multicolumn{1}{|c|}{ Rata-rata } & $30 \%$ & $36 \%$ & $43 \%$ \\
\hline
\end{tabular}

Selain menghitung nilai kecocokan antara hasil pemeringkatan model regresi dengan pemeringkatan yang dilakukan oleh pakar, pada tahap ini juga dilakukan penghitungan nilai kecocokan antara model pemeringkatan tanpa regresi, yaitu hanya mempertimbangkan nilai helpfulness ratio saja, dengan model pemeringkatan yang dilakukan oleh pakar. Hasil penghitungan ini kemudian akan dibandingkan dengan hasil penghitungan nilai kecocokan pemeringkatan model regresi untuk menentukan model mana yang memiliki kinerja lebih baik.

Hasil penghitungan nilai kecocokan model pemeringkatan dengan helpfulness ratio saja dengan model pemeringkatan oleh manusia dapat dilihat pada Tabel 5. Dari tabel tersebut dapat disimpulkan bahwa rata-rata nilai kecocokan untuk data ulasan dari situs web Flipkart adalah $25 \%$, nilai rata-rata kecocokan untuk data ulasan dari situs web Bol adalah $32 \%$, dan rata-rata nilai kecocokan untuk data ulasan dari situs web Ceneo adalah 26\%. Sehingga apabila dihitung secara keseluruhan, rata-rata nilai kecocokan model pemeringkatan dengan helpfulness ratio saja mempunyai rata-rata nilai kecocokan sebesar $31 \%$. Hal ini menunjukkan bahwa model pemeringkatan dengan helpfulness ratio saja memiliki rata-rata nilai kecocokan yang lebih kecil daripada model pemeringkatan hasil regresi dengan selisih sebesar 6\%. Dari analisis tersebut dapat ditarik kesimpulan bahwa model pemeringkatan berdasarkan hasil model regresi memiliki kinerja yang lebih baik daripada model pemeringkatan yang hanya bedasarkan nilai helpfulness ratio saja.

Tabel 5. Hasil Penghitungan Nilai Kecocokan Model Pemeringkatan berdasarkan Helpfulness Ratio

\begin{tabular}{|c|c|c|c|}
\hline Jenis Produk & Flipkart & Bol & Ceneo \\
\hline Pendingin Ruangan & $38 \%$ & $42 \%$ & $42 \%$ \\
\hline Mesin Cuci & $30 \%$ & $16 \%$ & $36 \%$ \\
\hline Televisi & $20 \%$ & $38 \%$ & $42 \%$ \\
\hline Kulkas & $16 \%$ & $30 \%$ & $24 \%$ \\
\hline Kamera & $20 \%$ & $36 \%$ & $36 \%$ \\
\hline Rata-rata & $25 \%$ & $32 \%$ & $26 \%$ \\
\hline
\end{tabular}

Perbandingan antara nilai kecocokan pada model pemeringkatan berdasarkan hasil regresi terhadap model pemeringkatan berdasarkan nilai helpfulness ratio saja untuk data ulasan dari situs web Flipkart digambarkan menggunakan diagram batang pada Gambar 2 Dalam Gambar 2 dapat terlihat bahwa pada seluruh data ulasan produk, model pemeringkatan berdasarkan hasil regresi mempunyai rata-rata nilai kecocokan yang lebih tinggi daripada model pemeringkatan berdasarkan nilai helpfulness ratio saja. 


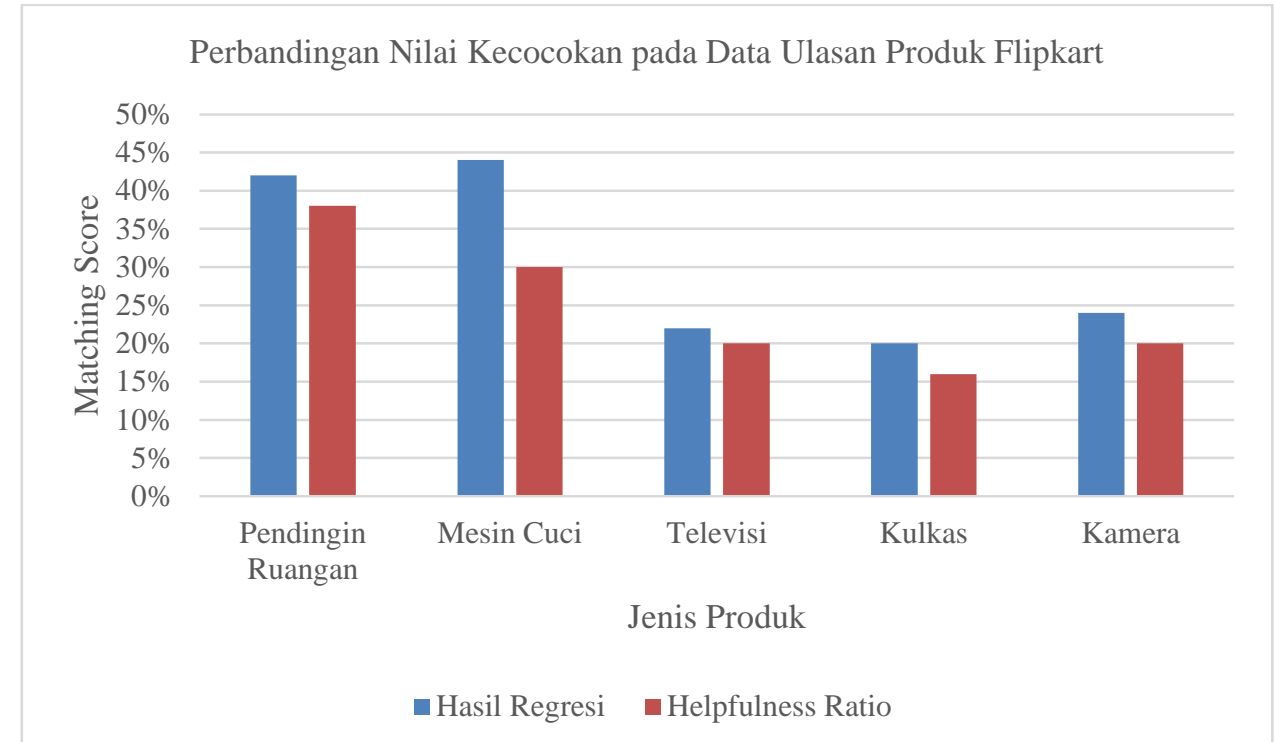

Gambar 2. Diagram Perbandingan Nilai Kecocokan pada Data Ulasan Produk dari Situs Web Flipkart

Perbandingan antara rata-rata nilai kecocokan pada model pemeringkatan berdasarkan hasil regresi terhadap model pemeringkatan menggunakan helpfulness ratio saja pada data ulasan dari situs web Bol digambarkan dengan diagram batang pada Gambar 3 Dalam Gambar 3 dapat terlihat bahwa pemeringkatan berdasarkan hasil regresi mempunyai nilai rata-rata kecocokan pada data ulasan produk pendingin ruangan, mesin cuci, kulkas, dan kamera. Sedangkan pada data ulasan produk televisi, model pemeringkatan dengan helpfulness ratio memiliki nilai rata-rata kecocokan lebih tinggi pada data ulasan produk televisi saja.

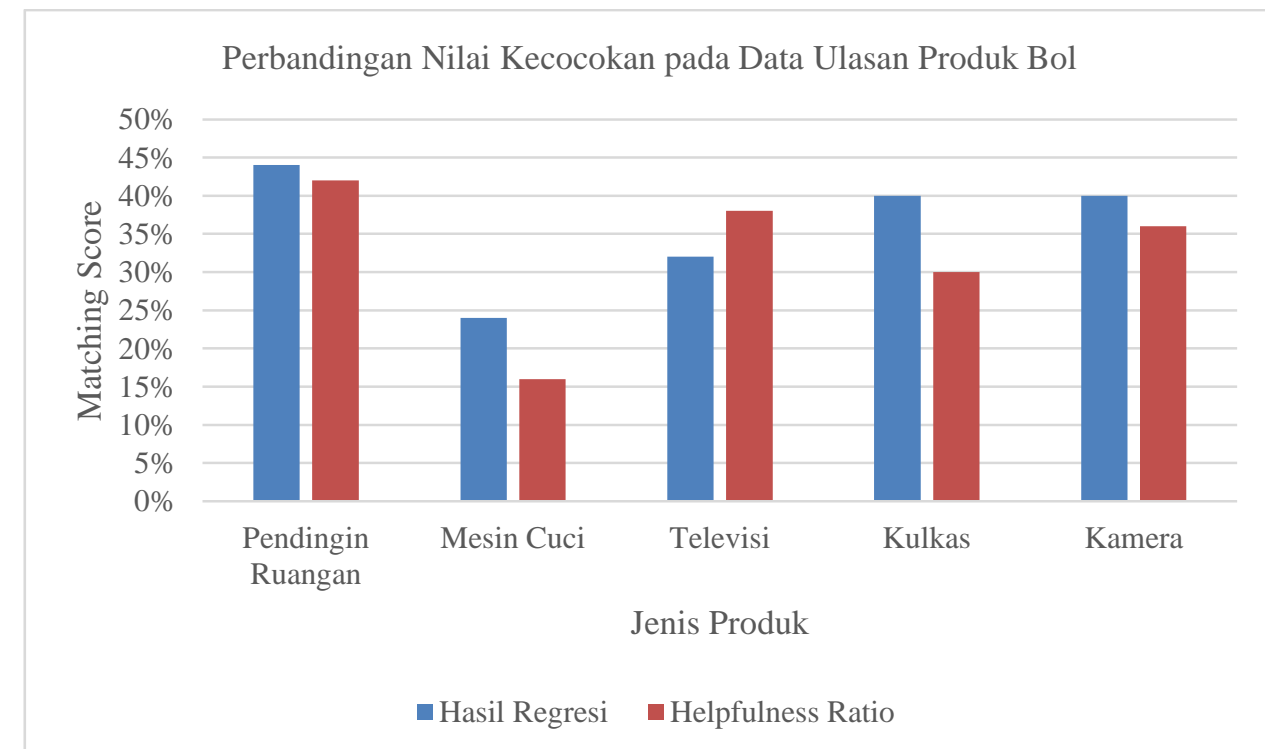

Gambar 3. Diagram Perbandingan Nilai Kecocokan pada Data Ulasan Produk dari Situs Web Bol

Perbandingan antara rata-rata nilai kecocokan pada model pemeringkatan berdasarkan hasil regresi terhadap model pemeringkatan menggunakan helpfulness ratio saja pada data 
ulasan dari situs web Ceneo digambarkan dengan diagram batang pada Gambar 4 Dalam Gambar 4 dapat terlihat bahwa pemeringkatan berdasarkan hasil regresi mempunyai nilai ratarata kecocokan pada data ulasan produk pendingin ruangan, mesin cuci, kulkas, dan kamera. Sedangkan pada data ulasan produk televisi, model pemeringkatan dengan helpfulness ratio memiliki nilai rata-rata kecocokan lebih tinggi pada data ulasan produk televisi saja.

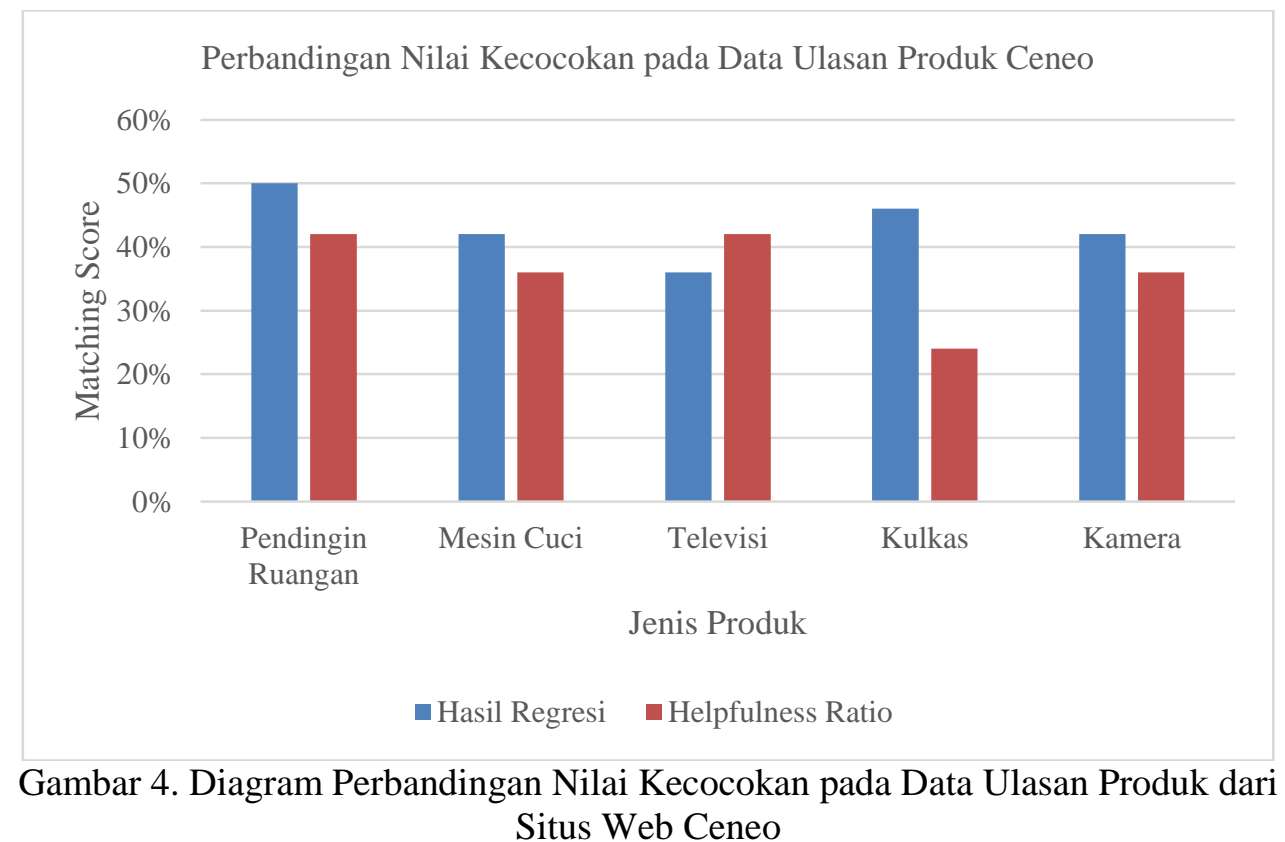

\section{KESIMPULAN}

Hasil penelitian menunjukkan bahwa model pemeringkatan berdasarkan hasil regresi mempunyai performa yang lebih baik dibandingkan model pemeringkatan berdasarkan nilai helpfulness ratio saja. Dari pengujian perbandingan nilai kecocokan dapat disimpulkan bahwa:

- Rata-rata nilai kecocokan untuk model pemeringkatan berdasarkan hasil regresi mempunyai nilai yang lebih tinggi daripada rata-rata nilai kecocokan model pemeringkatan berdasarkan helpfulness ratio saja. Selisih nilai rata-rata kecocokan mencapai $6 \%$.

- Model pemeringkatan berdasarkan hasil regresi mempunyai rata-rata nilai kecocokan yang lebih tinggi pada 13 dari 15 dataset ulasan produk. Hal ini menunjukkan bahwa model pemeringkatan berdasarkan hasil regresi mempunyai kinerja yang lebih baik daripada model pemeringkatan berdasarkan nilai helpfulness ratio saja.

\section{SARAN}

Pada data ulasan yang digunakan, terdapat beberapa kata yang masih kurang sempurna dalam penulisan, sehingga kata tersebut tidak dapat dikenali pada tahap ekstraksi aspek dan analisis sentimen. Kekurangan ini dapat disempurnakan pada penelitian lebih lanjut dengan menambahkan langkah penyempurnaan ejaan kata pada tahap praproses data sebelum data ulasan digunakan dalam tahap aspek ekstraksi. 


\section{DAFTAR PUSTAKA}

[1] Y. Zhou, S. Yang, y. li, Y. chen, J. Yao and A. Qazi, 2020, "Does The Review Deserve More Helpfulness When Its Title Resembles The Content? Locating Helpful Reviews by Text Mining," Information Processing and Management, Vol. 57.

[2] C.-Y. Lai, Y.-M. Li and L.-F. Lin, 2017, "A Social Referral Appraising Mechanism for The E-Marketplace," Information \& Management, Vol. 54, Hal. 269-280.

[3] S. Chatterjee, 2019, "Drivers of Helpfulness of Online Hotel Reviews: A Sentiment and Emotion Mining Approach," International Journal of Hospitality Management.

[4] S. P. Eslami, M. Ghasemaghaei and K. Hassanein, 2018, "Which Online Reviews Do Consumers Find Most Helpful? A Multi-Method Investigation," Decision Support Systems, Vol. 113, Hal. 32-42.

[5] X. Sun, M. Han and J. Feng, 2019, "Helpfulness of Online Reviews : Examining Review Informativeness and Classification Thresholds by Search Products and Experience Products," Decision Support Systems, Vol. 124, hal. 1-11.

[6] S. M. Mudambi and D. Schuff, 2010, "What Makes A Helpful Online Review? A Study of Customer Reviews on Amazon.com," MIS Quarterly, No. 1, Vol. 34, Hal. 185-200.

[7] S.-T. Li, T.-T. Pham and H.-C. Chuang, 2019, "Do Reviewers' Words Affect Predicting Their Helpfulness Ratings? Locating Helpful Reviewers by Linguistics Styles," Information \& Management, Vol. 56, Hal. 28-38.

[8] F. Wang and S. Karimi, 2019, "This Product Works Well (for me): The Impact of FirstPerson Singular Pronouns on Online Review Helpfulness," Journal of Business Research, Vol. 104, Hal. 283-294.

[9] V. Srivastava and A. D. Kalro, 2019, "Enhancing The Helpfulness of Online Consumer Reviews: The Role of Latent (Content) Factors," Journal of Interactive Marketing, Vol. 48, Hal. 33-50.

[10] M. Salehan and D. J. Kim, 2016, "Predicting The Performance of Online Consumer Reviews: A Sentiment Mining Approach to Big Data Analytics," Decision Support Systems, Vol. 81, Hal. 30-40.

[11] M. Malik and A. Hussain, 2019, "An Analysis of Review Content And Reviewer Variables That Contribute to Review Helpfulness," Information Processing And Management, Vol. 54, Hal. 88-104.

[12] J.-N. Wang, J. Du and Y.-L. Chiu, 2020, "Can Online User Reviews Be More Helpful? Evaluating and Improving Ranking Approaches," Information \& Management, no. 8, vol. 57.

[13] S. Saumya, J. P. Singh, A. M. Baabdullah, N. P. Rana and Y. K. Dwivedi, 2018, "Ranking Online Consumer Reviews," Electronic Commerce Research and Applications, 
Vol. 29, Hal. 78-89.

[14] M. E. Mowlaei, M. S. Abadeh and H. Keshavarz, 2020, "Aspect-Based Sentiment Analysis Using Adaptive Aspect-Based Lexicons," Expert Systems With Applications, Vol. 148, hal. 1-13.

[15] P. D. Turney, 2002, "Thumbs Up or Thumbs Down? Semantic Orientation Applied to Unsupervised Classification of Reviews, " in Proceedings of the 40th Annual Meeting of the Association for Computational Linguistics (ACL), Philadelphia.

[16] E. Brunova and Y. Bidulya, 2017, "Aspect Extraction and Sentiment Analysis in User Reviews in Russian About Bank Service Quality," Moscow.

[17] N. Jindal and B. Liu, 2008, "Opinion Spam and Analysis," in Web Search and Data Mining, California. 